\title{
An Application To The Travelling Salesman Problem
}

\author{
Damitha Bandara \\ Management Department, Albany State University, Albany, GA, USA
}

\begin{abstract}
ABC Appliances (Pvt) Ltd.,one of the leading companies in Sri Lanka has supplied and installed a very large number of air condition units all over the country. The company is currently provides a comprehensive after sales service for its customers. At present the service department is interesting in reducing the cost involving in regular after sale servicers. In this research we proposed a Travelling Salesman Problem (TSP) approach tominimize the cost involving in service tours. We used nearest neighbourhood search algorithm to obtain the solutions to the TSP. Computational examples show that the new service routes obtained using this algorithm will reduce the travelling cost significantly in comparison to existing routs.
\end{abstract}

\section{KEYWORDS}

Travelling Salesman Problem, Greedy Algorithm, NP Hard, Heuristic, Meta Heuristic, Nearest Neighbour

\section{INTRODUCTION}

ABC Appliances Company (pvt) Ltd., one of the leading companies in Sri Lanka, was established in November 1991 for the purpose of marketing a range of brand products; air conditioners, water pumps, ceiling fans, table and pedestal fans, four-wheel tractors and generators. The company is currently distributing these products island wide through a strong dealer network. The ABC Appliances Company, not only distributing air conditioners and accessories but also provides a comprehensive after sales service for its customers. The company maintains a service department consists of a service manager, three engineers, thirty technicians, five motor vehicles and three motor bicycles to provide after sales for the customers. The main responsibilities of the department are to service the air conditioners purchased from the company and deploy mobile teams to attend break-downs.

At present the service department is interesting in reducing the cost involving in regular after sale servicers for air conditioners. The service department has to visit its customers once a month to service the air conditioners. These customers are located island wide and therefore, travelling cost contributes a reasonable amount for the total cost on top of service cost. Thus the goal of this work is to propose scientific approach to minimize the travelling cost.

In this research we used the concept of Travelling Salesman Problem (TSP)([18],[19],[20])to determine the regular service routs that minimizes the travelling costs. In the classical TSP problem, the objective is to find the best possible way of visiting all the cities exactly once and returning to the starting point for a given set of cities and the cost of travel (or distance) between each possible pairs. Likewise, the serve department of ABC Company starts their service journeys from the head office and return back to the head office after visiting the locations that

DOI: $10.5121 /$ oraj.2017.4402 
need to be serviced. Thus applying TSP approach to determine optimal service routs for ABC Company is relevant.

The TSP problem is a NP hard combinatorial optimization problem (COP) ([1],[9],[8]). Combinatorial optimization is a branch of discrete optimization and the COPs have a finite set of possible solutions. The best way to solve a COP is to enumerate all the feasible solutions in the search space using algorithms such as the branch and bound algorithm and the branch and cut algorithm ([10], [12],[16], [17]). However, enumerating all the feasible solutions is not always possible, thus solving this problem optimally in real time is impractical, especially as the search space complexity grows, the execution time can increase exponentially, making the search for a solution is not feasible ([1],[3],[9]). In this case the COP is defined as NP-hard (nondeterministic polynomial-time) COP ([6], [10],[15]). Because of the difficulties faced with enumerating all feasible solutions using these methods, alternative methods such as approximation algorithms, heuristic algorithms, and metaheuristic algorithm have been proposed. Therefore, in this research project we used a heuristic algorithm proposed for the TSP based on nearest neighbourhood search [7] to obtain the best route for the ABC Company.

The data collected from $\mathrm{ABC}$ Company is used in this algorithm to find the best routs for the company. Computational examples show that the new service routes obtained using this algorithm will reducethe travelling cost significantly in comparison to existing routs.

\section{Problem Statement}

ABC Appliances (Pvt) Ltd. has supplied and installed a very large number of air condition units all over the country. According to the service agreements, the company has to attend to urgent break- down calls promptly and to carry out regular service visits to each and every unit already installed. At present, the service department is following a schedule of places to be visited, which is prepared by its Management Department. According to the present schedule, the entire country is divided into six regions for the convenience of carrying out regular service tours. The six regions are given below. Each region is corresponding to a Tour/Route. Therefore, currently there are six different service tours/ routs in place.

\section{Region 1(Tour No 1)}

Colombo, Nittabuwa, Peradeniya, kegalle, Gampola, Mawanella, Nawalapitiya, Kothmale, Akurana, Kandy, Kundasale, Digana, Mahiyangana, Matale, Pussellawa, Dehiyattakandiya, Colombo.

Region 2 (Tour No 2)

Colombo, Anuradapura, Kaduruwella, Manampitiya,Valachchanai, Batticalo, Samanthurai, Ampara, Colombo.

Region 3 (Tour No 3)

Colombo, Dhargatown, Ahungalla, Hikkaduwa, Galle, Beruwela, Katukurunda, Matara Colombo.

Region 4 (Tour No 4)

Colombo, Kochchikade, Wennappuwa, Lunuwila, Marawila, Chilaw, Puttalam, Wariyapola, Hettipola, Kuliyapitiya, Narammala, Colombo. 
Region 5 (Tour No 5)

Colombo, Awissawella, Eheliyagoda, Rathnapura, Kalawana, Rathnapura, Pelmadulla, Embilipitiya, Middeniya, Hungama, Tangalle, Hungama, Tissamaharamaya, Katharagama, Moneragala, Badulla, Welimada, Bandarawella, Balangoda, Pelmadulla, Colombo.

Region 6 (Tour No 6)

Colombo, Kurunegala, Uhumiya, Melsiripura, Galewela, Dambulla, Madawachchiya, Vavniya, Kebithigollewa, Tricomalee, Habarana, Colombo.

Apparently the Management Department has not taken into account the important factors such as optimal route in preparing the schedule. Hence, the Service Department is in the process of analysing the present schedule for the purpose of amending them suitably to minimize the time and cost involved in attending to regular services of air conditioner units. As there is a stiff competition for supply and installation of air conditioners it has become very essential to prepare a well-planned schedule so that the service department will be able to carry out regular service tours efficiently.

\section{Methodology}

First, we represent the cities and the roads connecting them in a network, which is called a road network. This will enable us to distinguish the paths currently used by the service department and the other alternative paths, which can be considered to reduce the travelling distance. A network consists of a set of points called nodes, with certain pairs of nodes being joined by lines called branches and a flow of some type on its branches ([2],[4]). In this research we consider a road network, where nodes are considered as cities, branches as roads linking these cities and flow as distance between any two cities. The problem that we deal here can be represented in six different road networks. The Table1 represents the distances between the cites for Tour No.1 and Figure 1 shows the road associated with tour No. 1. Remaining tour informationare given in the Appendix.

\begin{tabular}{|l|l|l|}
\hline Origin & Destination & Distance (km) \\
\hline Akurana & Kandy & 11 \\
\hline Ambepussa & Kegalle & 17 \\
\hline Colombo & Nittambuwa & 40 \\
\hline Gampola & Nawalapitiya & 13 \\
\hline Gampola & Pussaellawa & 22 \\
\hline Kandy & Kurunegala & 42 \\
\hline Kandy & Peradeniya & 7 \\
\hline Kegalle & Mawanella & 13 \\
\hline Kundasale & Digane & 12 \\
\hline Kundasale & Kandy & 5 \\
\hline Mahiyangana & Dehiattakandiya & 35 \\
\hline Mahiyangana & Digane & 49 \\
\hline Matale & Akurana & 15 \\
\hline Mawanella & Peradeniya & 19 \\
\hline Nittambuwa & Ambepussa & 20 \\
\hline Peradeniya & Gampola & 18 \\
\hline
\end{tabular}

Table 1. Distance Table for Tour No 1 
Operations Research and Applications: An International Journal (ORAJ), Vol.4, No.3/4, November 2017

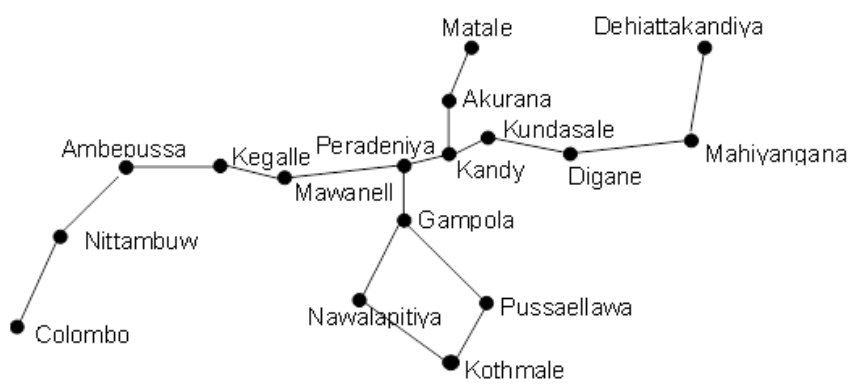

Figure 1. Network Diagram for Tour No 1

Since the service department is located at Colombo, the service tours should start from Colombo and back to Colombo after visiting the intermediate cities. As our objective is to minimize the travelling cost, which depends on the travelling distance, our approach should be to visit each city exactly once and come back to the starting point, which is Colombo. As mentioned in the Introduction, this problem can be formulated as TSP which is one the hard NP COP. Thus, we emphasize the mathematical formulation of TSP in Section 3.1 to obtain the best routs for ABC Company.

\subsection{Mathematical Formulation Of The Traveling Salesman Problem}

There are several mathematical formulations of the traveling salesman problem, and the one we have chosen to present in this report is due to Miller, Tuker, and Zemlin (1960)[14]. We begin the formulation process by first numbering the cities from 1 through $n$, with city 1 being designated as the home city with index set $I=\{i: i=1, \ldots, n\}$. Let $x \in R^{n}$ be the decision variable defined as follows:

$$
x_{i, j}=\left\{\begin{array}{cc}
1, & i \text { f city } j \text { is visited immidiately following city } i \\
0, & \text { otherwise }
\end{array}\right.
$$

Let $c_{i, j}$ be the traveling distance between city $i$ and city $j$. The combinatorial optimization model of the TSP can be formulated as follows:

$$
\begin{gathered}
\text { Minimize } \sum_{i \in I} \sum_{j \in J} C_{i, j} x_{i, j} \\
\text { Subject to } \quad \sum_{j=1}^{n} x_{i, j}=1, \quad \text { for } i \in I \quad \rightarrow(1) \\
\sum x_{i, j}=1, \quad \text { for } j \in I \quad \rightarrow(2) \\
t_{i}-t_{j}+n x_{i, j} \leq n-1, \quad \text { for } i, j \in I \quad \rightarrow(3)
\end{gathered}
$$

where $t_{i}, t_{j}$ are arbitrary real numbers.

Constraints (1) ensure that on the travelling salesman tour, each city is followed by exactly one city. Similarly, constraints (2) specify that a unique city is visited immediately before city. The remaining constraints (3) are referred to as subtour elimination constraints. Their purpose is to 
Operations Research and Applications: An International Journal (ORAJ), Vol.4, No.3/4, November 2017

ensure that a single tour result rather than a number of disjoint sub-tours. Because city 1 is the home city, the constraints operate by ensuring that every tour contains city 1 .

\subsection{Heuristic Algorithm For The Travelling Salesman Problem}

In this section we present the algorithm that we used to obtain the best solution of the TSP. In this algorithm, we assume that the given road network is a complete road network. The concept of the nearest neighbour search is used in this algorithm. The key of this algorithm is to always visit the nearest city by minimizing the traveling $\operatorname{cost} c_{i, j}$ for $i, j \in I$ and return to the starting city when all the other cities are visited.The pseudocode of the algorithm is given in Figure 2. In this algorithm the symbol $\bar{I}$ denote index set of the currently visited cities. The algorithm starts with a homecity $k$. Starting from the home city $k$ the algorithm finds the nearest unvisited city by minimizing the traveling $\operatorname{cost} c_{k, i}$ where in $i \in I \backslash \bar{I}$ and visit that city. This algorithm is run until all cities are visited and return to the home city $k$. The algorithm returns the tour start with home city $k$ and the corresponding cost.

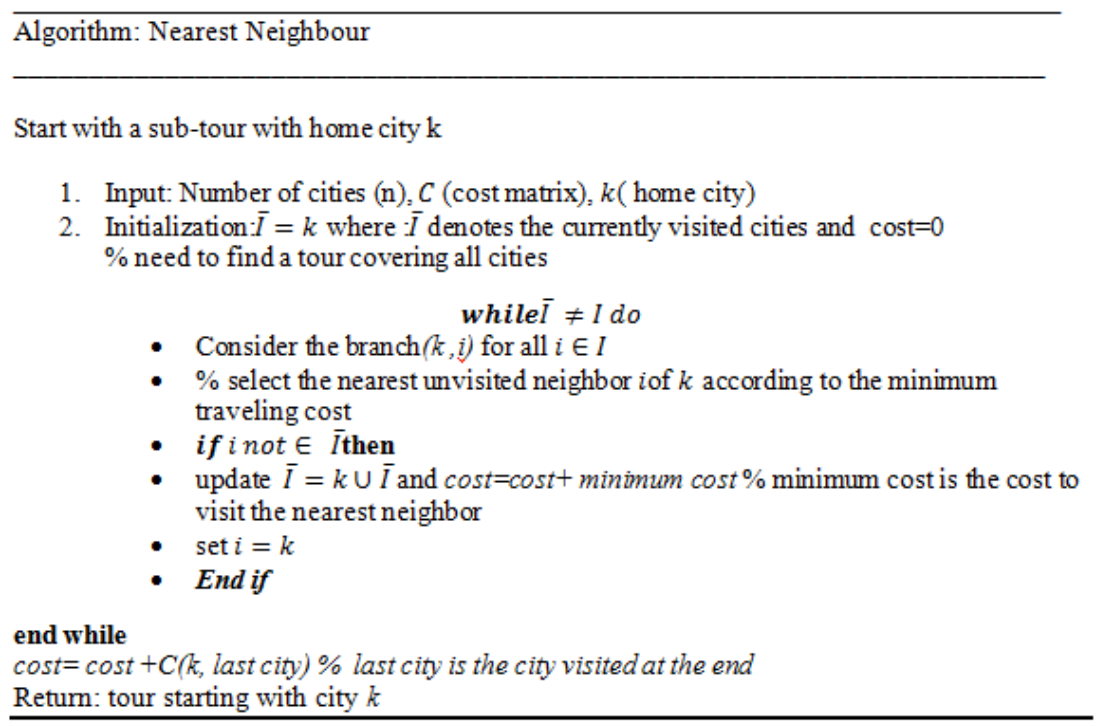

Figure 2

\section{Computational Results}

After analysing the road network and the current travel schedule it was revealed that the existing six routes can be reduced to three routes. Therefore, the new travel schedule is prepared by considering only three routes. Applying the Nearest neighbourhood search algorithm to these three routes we have arrived at a best solution for each region as shown below:

Proposed Service Tours

\section{Region 1 (Tour 1)}

Colombo, Nittabuwa, Kegalle, Mawanella, Peradeniya, Kandy, Akurana, Matale, Digana, Mahiyangana, Dehiyattakandiya, Kaduruwela, Valachchenai, Batticalo, Amparai, Monaragala, Badulla, Bandarawela, Welimada, Pussellawe, Gampola, Nawalapitiya, Awssawella, Colombo. 
Region 2 (Tour 2)

Colombo, Awissawella, Eheliyagoda, Rathnapura, Kalawana, Pelmadulla, Balangoda, Wellawaya, Buttala, Kataragama, Thissamaharamaya, Hambantota, Hungama, Embilipitiya, Middeniya, Tangalle, Matara, Aluthgama, Galle, Hikkaduwa, Ahungalle, Dargatown, Beruwela, Katukurunda, Colombo.

Region 3 (Tour 3)

Colombo, Katunayake, Nigambo, Kochchikade, Wennappuwa, Lunuwila, Marawila, Chilaw, Puttalam, Anuradapura, Madawachchiya, Vayuniya, Tricomalee, Habarana, Dambulla, Wariyapola, Hettipola, Kuliyapitiya, Narammala, Kurunegala, Colombo.
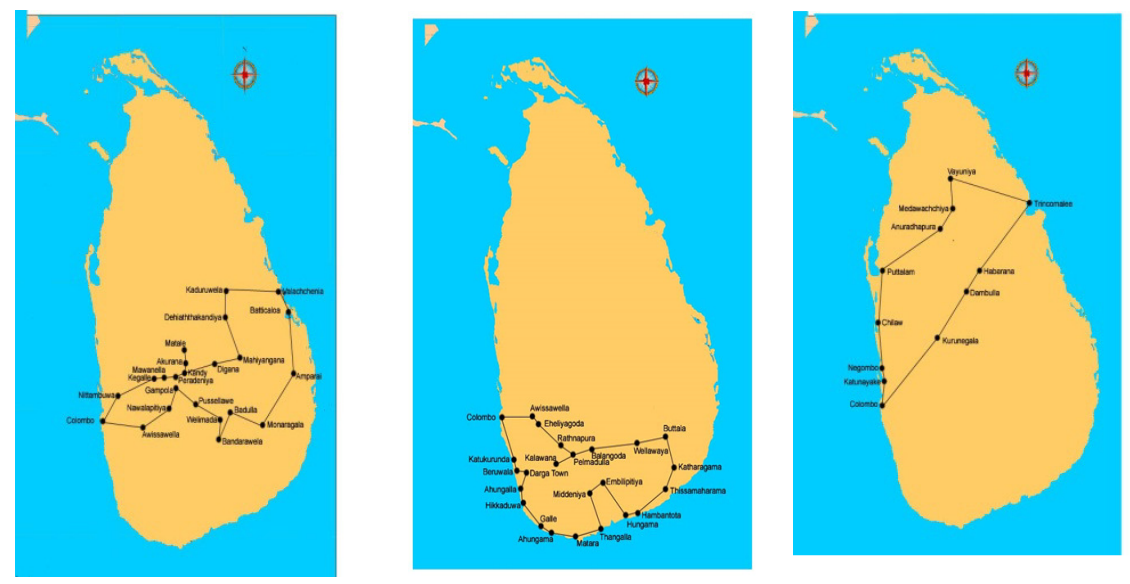

Figure 3-Proposed Service Routs

The solution given above is by far the best solution with respect to the distance. In fact there are other factors, which contribute to optimal route such as travelling time. But in this report we restrict our problem only to distance. In the discussion we compare the travelling cost for the current schedule with the proposed schedule. It is our understanding that this travelling cost can even reduce further if all the factors contribute to the traveling cost can be considered in finding the optimal route.

\section{Conclusion And Discussion}

Travelling cost for the current schedule and the proposed schedule are compared below:

\begin{tabular}{|l|l|l|l|}
\hline \multicolumn{2}{|l|}{ Current schedule } & \multicolumn{2}{l|}{ Proposed schedule } \\
\hline Tour No & Travelling $(\mathbf{k m})$ & Tour No & Travelling $(\mathbf{k m})$ \\
\hline 1 & 519 & 1 & 677 \\
\hline 2 & 782 & 2 & 856 \\
\hline 3 & 246 & 3 & 544 \\
\hline 4 & 420 & & \\
\hline 5 & 790 & & \\
\hline 6 & 605 & & \\
\hline Total & $\mathbf{3 3 6 2}$ & Total & $\mathbf{2 0 7 7}$ \\
\hline
\end{tabular}

Table 2.Comparison- Current schedule vs Proposed schedule 
Operations Research and Applications: An International Journal (ORAJ), Vol.4, No.3/4, November 2017

Table 2 exhibits the traveling distance for the current schedule and for the proposed schedule respectively.Company has incurred a total traveling distance of 3362 as per month by implementing the travel schedule prepared by the company's management division. This distance can be reduced to 2077 by implementing the proposed routs by applying TSP approach. This shows that the company can reduce the travelling distance by about $38 \%$. This is by any mean a very significant reduction. Also, as a result the company can provide an efficient and a better service to the clients. The following two factors were not being considered in the proposed method:

1. Number of air conditioner units to be serviced in a city was not considered.

2. Average time to service air condition units was not considered.

(This may vary according to the size of the unit and the time delays due to various reasons beyond the control of the technicians.)

However, this proposed method can be further developed by taking corrective measures to minimize the effects of the above-mentioned shortcomings.

\section{ACKNOWLEDGEMENTS}

It is our pleasure to acknowledge the General Manger, Service Manager and the staff of the ABC Company for the data they provided to support this research.We also like to express our heartfelt gratitude to Dr. W.B. Daundasekara for his guidance and support.

\section{REFERENCES}

[1] Bandara, D., \&Weerasena, L. (2016, January). Metaheuistic Algorithms to Solve the Reserve Design Problem.In International Conference on Enterprise Marketing and Globalization (EMG). Proceedings (p. 107). Global Science and Technology Forum.

[2] Bazaraa, M. S., Jarvis, J. J., \&Sherali, H. D. (2011). Linear programming and network flows. John Wiley \& Sons.

[3] Deepmala. (2014). A study on fixed point theorems for nonlinear contractions and its applications, Ph.D Thesis, Pt. Ravishankar Shukla University, Raipur 492 010, Chhatisgarh, India.

[4] Foulds, L. R. (2012). Graph theory applications. Springer Science \& Business Media.

[5] Grötschel, M., \& Holland, O. (1991). Solution of large-scale symmetric travelling salesman problems.Mathematical Programming, 51(1), 141-202.

[6] Hartmanis, J. (1982). Computers and intractability: a guide to the theory of NP-completeness (michael r. garey and david s. johnson). Siam Review, 24(1), 90.

[7] Helsgaun, K. (2000). An effective implementation of the Lin-Kernighan traveling salesman heuristic.European Journal of Operational Research, 126(1), 106-130.

[8] Jünger, M., Reinelt, G., \& Rinaldi, G. (1995). The traveling salesman problem.Handbooks in operations research and management science, 7, 225-330.

[9] Kann, V. (1992). On the approximability of NP-complete optimization problems (Doctoral dissertation, Royal Institute of Technology, Sweden).

[10] Land, A. H., \&Doig, A. G. (1960). An automatic method of solving discrete programming problems.Econometrica: Journal of the Econometric Society, 497-520. 
Operations Research and Applications: An International Journal (ORAJ), Vol.4, No.3/4, November 2017

[11] Little, J. D., Murty, K. G., Sweeney, D. W., \& Karel, C. (1963). An algorithm for the traveling salesman problem.Operations research, 11(6), 972-989.

[12] Mitchell, J. E. (2002). Branch-and-cut algorithms for combinatorial optimization problems.Handbook of applied optimization, 65-77.

[13] Miller, D., \&Pekny, J. (1991). Exact solution of large asymmetric traveling salesman problems.Science, 251(4995), 754-761.

[14] Miller, C. E., Tucker, A. W., \&Zemlin, R. A. (1960). Integer programming formulation of traveling salesman problems.Journal of the ACM (JACM), 7(4), 326-329.

[15] Mishra, L. N. (2017). On existence and behaviour of solutions to some nonlinear integral equations with Applications, Ph. D. Thesis, National Institute of Technology, Silchar 788 010, Assam, India.

[16] Mishra, V. N. (2007).Some Problems on Approximation of Functions in Branch Spaces, Ph. D. Thesis, Indian Institute of Technology, Roorkee 247 667, Uttarakhand, India.

[17] Rosenkrantz, D. J., Stearns, R. E., \& Lewis, P. M. (2009). An analysis of several heuristics for the traveling salesman problem.Fundamental Problems in Computing, 1, 45-69.

[18] http://eu.wikipedia.org/wki/travelling_salesman_problem\#Heuristics

[19] http://students.ceid.upatras.gr/ papagel/project/tspprobl.htm

[20] http://en.wikipedia.org/wiki/Traveling salesman problem

\section{AuTHORS}

DamithaBandara-Assistant Professor of Supply Chain Management Albany State University, Albany, GA. USA College of Business

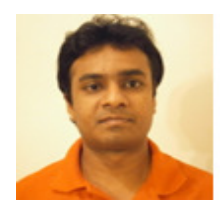


Operations Research and Applications: An International Journal (ORAJ), Vol.4, No.3/4, November 2017

\section{APPENDIX}

Table 4 -Distance Table for Tour No. 02

\begin{tabular}{|c|c|c|}
\hline Origin & Destination & Distance (km) \\
\hline Akurana & Kandy & 11 \\
\hline Alawwa & Polgahawela & 8 \\
\hline Ambepussa & Alawwa & 9 \\
\hline Ambepussa & Kegalle & 17 \\
\hline Ampara & Mahaoya & 60 \\
\hline Anuradapura & Nikaweratiya & 74 \\
\hline Anuradapura & Rambewa & 15 \\
\hline Batticalo & Samanturei & 50 \\
\hline Chenkaladi & Batticalo & 13 \\
\hline Chenkaladi & Mahaoya & 40 \\
\hline Habarana & Polonnaruwa & 41 \\
\hline Kaduruwela & Manampitiya & 10 \\
\hline Kandy & Kurunegala & 42 \\
\hline Kandy & Peradeniya & 7 \\
\hline Kegalle & Mawanella & 13 \\
\hline Kegalle & Polgahawela & 16 \\
\hline Kundasale & Digane & 12 \\
\hline Kundasale & Kandy & 5 \\
\hline Mahaoya & Meegaswatte & 35 \\
\hline Mahiyangana & Digane & 49 \\
\hline Manampitiya & Thirikkanmadu & 45 \\
\hline Maradankadawala & Anuradapura & 33 \\
\hline Maradankadawala & Ganewalpola & 8 \\
\hline Mawanella & Peradeniya & 19 \\
\hline Meegaswatte & Mahiyangana & 30 \\
\hline Nittambuwa & Ambepussa & 20 \\
\hline Polgahawela & Kurunegala & 20 \\
\hline Polonnaruwa & Kaduruwela & 4 \\
\hline Samanturei & Ampara & 20 \\
\hline Thirikkanmadu & Valachchena & 5 \\
\hline Valachchena & Chenkaladi & 18 \\
\hline Vavuniya & Madewachchiya & 26 \\
\hline
\end{tabular}


Operations Research and Applications: An International Journal (ORAJ), Vol.4, No.3/4, November 2017

Table 5 -Distance Table for Tour No. 03

\begin{tabular}{|l|l|r|}
\hline \multicolumn{1}{|c|}{ Origin } & Destination & Distance (km) \\
\hline Ahungalla & Aluthgama & 19 \\
\hline Aluthgama & Beruwela & 5 \\
\hline Aluthgama & Dharga Town & 2 \\
\hline Dharga Town & Neluwa & 45 \\
\hline Galle & Hikkaduwa & 20 \\
\hline Hikkaduwa & Ahungalla & 22 \\
\hline Katukurunda & Beruwela & 11 \\
\hline Katukurunda & Colombo & 44 \\
\hline Neluwa & Hikkaduwa & 51 \\
\hline Galle & Matara & 35 \\
\hline Neluwa & Morawaka & 22 \\
\hline Matara & Morawaka & 40 \\
\hline
\end{tabular}

Table 6 -Distance Table for Tour No. 04

\begin{tabular}{|l|l|r|}
\hline \multicolumn{1}{|c|}{ Origin } & \multicolumn{1}{|c|}{ Destination } & Distance (km) \\
\hline Alawwa & Polgahawela & 8 \\
\hline Ambepussa & Alawwa & 9 \\
\hline Colombo & Katunayake & 25 \\
\hline Hettipola & Chilaw & 30 \\
\hline Hettipola & Kuliyapitiya & 15 \\
\hline Kochchikade & Nigambo & 7 \\
\hline Kurunegala & Uhumiya & 7 \\
\hline Lunuwila & Kochchikade & 8 \\
\hline Madampe & Chilaw & 12 \\
\hline Madampe & Kuliyapitiya & 25 \\
\hline Marawila & Madampe & 7 \\
\hline Marawila & Wennappuwa & 7 \\
\hline Narammala & Alawwa & 16 \\
\hline Nigambo & Katunayake & 8 \\
\hline Nittambuwa & Ambepussa & 20 \\
\hline Polgahawela & Kurunegala & 20 \\
\hline Puththalam & Chilaw & 55 \\
\hline Puththalam & Nikaweratiya & 59 \\
\hline Uhumiya & Narammala & 12 \\
\hline Wariyapola & Hettipola & 20 \\
\hline Wariyapola & Kurunegala & 15 \\
\hline Wariyapola & Nikaweratiya & 6 \\
\hline Wennappuwa & Kochchikade & 8 \\
\hline Wennappuwa & Lunuwila & 3 \\
\hline
\end{tabular}


Operations Research and Applications: An International Journal (ORAJ), Vol.4, No.3/4, November 2017

Table 7 -Distance Table for Tour No. 05

\begin{tabular}{|c|c|c|}
\hline Origin & Destination & Distance (km) \\
\hline Awissawella & Eheliyagoda & 14 \\
\hline Badulla & Bandarawela & 26 \\
\hline Badulla & Passara & 19 \\
\hline Badulla & Welimada & 30 \\
\hline Balangoda & Beragala & 30 \\
\hline Beragala & Wellawaya & 23 \\
\hline Buttala & Kataragama & 40 \\
\hline Buttala & Wellawaya & 20 \\
\hline Colombo & Awissawella & 58 \\
\hline Eheliyagoda & Rathnapura & 29 \\
\hline Ginigathhena & Awissawella & 40 \\
\hline Ginigathhena & NuwaraEliya & 47 \\
\hline Hambanthota & Nonagama & 15 \\
\hline Hungama & Middeniya & 30 \\
\hline Hungama & Thangalla & 15 \\
\hline Kalawana & Rathnapura & 30 \\
\hline Kataragama & Thissamaharamaya & 20 \\
\hline Kumblwela & Badulla & 23 \\
\hline Kumblwela & Bandarawela & 7 \\
\hline Madhampe & Embilipitiya & 40 \\
\hline Madhampe & Pelmadulla & 15 \\
\hline Mahiyangana & Badulla & 57 \\
\hline Mathugama & Kalawana & 36 \\
\hline Middeniya & Embilipitiya & 17 \\
\hline Monaragala & Buttala & 20 \\
\hline Nawalapitiya & Ginigathhena & 10 \\
\hline Nonagama & Embilipitiya & 33 \\
\hline Nonagama & Hungama & 10 \\
\hline NuwaraEliya & Welimada & 18 \\
\hline Pannegamuwa & Wellawaya & 55 \\
\hline Pannegamuwa & Wirawila & 5 \\
\hline Passara & Monaragala & 58 \\
\hline Pelmadulla & Balangoda & 24 \\
\hline Rathnapura & Pelmadulla & 19 \\
\hline Thissamaharamaya & Pannegamuwa & 4 \\
\hline Thissamaharamaya & Wirawila & 7 \\
\hline Welimada & Bandarawela & 24 \\
\hline Wellawaya & Kumblwela & 21 \\
\hline Wirawila & Hambanthota & 20 \\
\hline
\end{tabular}


Operations Research and Applications: An International Journal (ORAJ), Vol.4, No.3/4, November 2017

Table 8 -Distance Table for Tour No. 06

\begin{tabular}{|l|l|r|}
\hline \multicolumn{1}{|c|}{ Origin } & \multicolumn{1}{c|}{ Destination } & Distance (km) \\
\hline Alawwa & Polgahawela & 8 \\
\hline Ambepussa & Alawwa & 9 \\
\hline Anuradapura & Rambewa & 15 \\
\hline Dambulla & Galewela & 15 \\
\hline Dambulla & Kekirawa & 20 \\
\hline Galewela & Melsiripura & 18 \\
\hline Habarana & Dambulla & 24 \\
\hline Horuwpathana & Kabithigollewa & 25 \\
\hline Horuwpathana & Mihinthale & 41 \\
\hline Horuwpathana & Trincomalee & 50 \\
\hline Kekirawa & Ganewalpola & 7 \\
\hline Kurunegala & Uhumiya & 7 \\
\hline Madewachchiya & Kabithigollewa & 23 \\
\hline Maradankadawala & Anuradapura & 33 \\
\hline Maradankadawala & Ganewalpola & 8 \\
\hline Maradankadawala & Kekirawa & 10 \\
\hline Maradankadawala & Mihinthale & 38 \\
\hline Melsiripura & Kurunegala & 25 \\
\hline Mihinthale & Anuradapura & 10 \\
\hline Mihinthale & Rambewa & 10 \\
\hline Polgahawela & Kurunegala & 20 \\
\hline Rambewa & Madewachchiya & 15 \\
\hline Trincomalee & Habarana & 85 \\
\hline Uhumiya & Narammala & 12 \\
\hline Vavuniya & Kabithigollewa & 22 \\
\hline Vavuniya & Madewachchiya & 26 \\
\hline & &
\end{tabular}

